\title{
Immunogold Staining Following Freeze Substitution and Low Temperature Embedding after Chemical Fixation or after Cryoimmobilization for Transmission Electron Microscopy (TEM)
}

\author{
Jeremy N. Skepper and Janet M. Powell
}

This protocol was adapted from "Ultrastructural Immunochemistry," Chapter 7, in Immunohistochemistry: Methods Express (ed. Renshaw), from the Methods Express series. Scion Publishing Ltd., Oxfordshire, UK, 2006.

\section{INTRODUCTION}

In this method for freeze substitution and low-temperature embedding in resin prior to immunogold staining, lightly fixed tissue pieces are cryoprotected by immersion in polypropylene glycol. The cryoprotected tissues are quench frozen and transferred under liquid nitrogen to vials containing frozen methanol or methanol containing uranyl acetate. The vials are transferred to a substitution vessel where the temperature can be controlled and a nitrogen atmosphere maintained. The temperature is raised (typically at $5^{\circ} \mathrm{C} / \mathrm{h}$ to $-90^{\circ} \mathrm{C}$ ) and maintained for $24 \mathrm{~h}$. This temperature is cold enough to prevent recrystallization of water and thus tissue disruption, but high enough for movement of water to occur and allow substitution with the liquid methanol. After $24 \mathrm{~h}, \sim 90 \%$ of the water has been substituted. The substitution medium is replaced and the temperature is raised to $-70^{\circ} \mathrm{C}$ for $24 \mathrm{~h}$. The substitution medium is changed again and the temperature is raised to $-50^{\circ} \mathrm{C}$. The tissue is impregnated with Lowicryl HM20 over a period of 1-5 d and the resin is polymerized by UV irradiation. Tissue is then sectioned and stained immunochemically with primary antibodies raised against antigens exposed on the surface of the sections, and primary antibodies are visualized by staining with secondary antibodies conjugated to colloidal gold particles. The immunochemically stained sections are contrast stained with uranyl acetate and lead citrate to reveal the ultrastructure of the cells, and are finally viewed by transmission electron microscopy (TEM). This is the simplest and most versatile of the post-embedding procedures.

\section{RELATED INFORMATION}

Ultrastructural Immunochemistry (Skepper and Powell 2008a) describes methods and considerations for the use of immunogold staining, including fixation, controls, resolution, and quantification. The following protocols provide detailed procedures for immunogold staining of various sections for TEM:

Immunogold Staining of Epoxy Resin Sections for Transmission Electron Microscopy (TEM) (Skepper and Powell 2008b)

Immunogold Staining of London Resin (LR) White Sections for Transmission Electron Microscopy (TEM) (Skepper and Powell 2008c)

Immunogold Staining of Ultrathin Thawed Cryosections for Transmission Electron Microscopy (TEM) (Skepper and Powell 2008d)

For more comprehensive descriptions of the range of techniques available, see Griffiths et al. (1993) and Skepper (2000). 


\section{MATERIALS}

CAUTIONS AND RECIPES: Please see Appendices for appropriate handling of materials marked with $<!>$, and recipes for reagents marked with $<\mathbf{R}>$.

\section{Reagents}

$<\mathrm{R}>$ Antibodies, primary (optimally diluted in PBSG)

$<\mathbf{R}>$ Antibodies, secondary (optimally diluted in PBSG)

Use a secondary antibody raised against the species of the primary antibody and conjugated to 10- or 15-nm colloidal gold particles.

$<$ R $>$ Formaldehyde $(4 \%)$ in PIPES

$<$ !>HM20 resin (100\%)

$<$ ! Prepare a 50:50 mixture of 100\% ( $/ \mathrm{v} / \mathrm{v})$ methanol and $100 \%(\mathrm{v} / \mathrm{v})$ deoxygenated HM20 resin (see Steps 10-11). HM20 is a low-temperature resin, providing low viscosity at low temperatures.

$<$ ! $>$ Lead citrate

$<$ ! Methanol $(100 \%, 50 \%[\mathrm{v} / \mathrm{v}])$

$<$ R $>$ PBSG

$<$ R $>$ PBS (1X) containing 30\% (v/v) polypropylene glycol

In addition, add 1\% bovine serum albumin (BSA) (W/v) if cells are used as the subject of study.

$<$ R $>$ Phosphate-buffered saline (PBS) $(\mathrm{pH} 7.6)$

PIPES buffer (0.1 M, pH 7.4)

$<$ !>Potassium hydroxide

Prepare a Petri dish containing a few grains of moistened potassium hydroxide.

$<$ ! Propane (liquid)

Sodium chloride $(0.9 \%, \mathrm{w} / \mathrm{v})$

Tissue (small pieces) or cells of interest

$<$ R $>$ Uranyl acetate $(0.05 \%)$ in $100 \%$ methanol

$<\mathrm{R}>$ Uranyl acetate (saturated) in $50 \%$ methanol

\section{Equipment}

Aluminum foil

Automated freeze substitution device and cryo-prep center (CPC) freezing station (Leica

Microsystems)

Centrifuge

Copper block (gold-coated) (optional; see Step 6.ii)

Dental wax (or Parafilm)

Dental wax is used as a clean hydrophobic surface on which to perform immunogold staining of thin sections mounted on TEM grids and floated on small drops of reagents.

Diamond trim tool and $45^{\circ}$ ultradiamond knife (Diatome AG)

Forceps (chilled metal or ceramic) and cooled wooden cocktail stick (see Step 7)

$<$ ! $>$ Liquid nitrogen

Microscope (transmission electron) (FEI Tecnai 120)

Nickel grids (400 mesh)

$<$ ! $>$ Nitrogen gas (dry)

Tubes (1.5-mL microcentrifuge)

Ultramicrotome (EM UCT; Leica Microsystems)

$<!>$ UV irradiation

Vials for frozen tissue

\section{METHOD}

\section{Tissue Preparation and Embedding}

In this protocol, fixed and cryoprotected tissues are quench frozen by plunging into liquid propane cooled by liquid nitrogen. Adequate freezing can also be obtained using nitrogen slush or even liquid nitrogen for very small samples. 
Alternatively, monolayers of cells or thin slices can be frozen rapidly, freeze substituted and low-temperature embedded with no chemical fixation at all (Monaghan and Robertson 1990; Skepper et al. 2001), a method suited to antigens that are sensitive to aldehyde fixation (see Fig. 1).

1. Rinse cells or small pieces of tissue twice in $0.9 \%$ sodium chloride.

2. Incubate samples in $4 \%$ formaldehyde in PIPES buffer containing $\mathrm{CaCl}_{2}$ for $1 \mathrm{~h}$ at $4{ }^{\circ} \mathrm{C}$. If the cells are adherent, scrape them free from the substrate and transfer to $1.5-\mathrm{mL}$ tubes.

Samples may be cryoimmobilized without chemical fixation; see Step 6.ii.

3. Rinse samples four times in 0.1 M PIPES buffer over a period of 20 min and twice in $\mathrm{H}_{2} \mathrm{O}$.

4. Incubate samples in $1 \mathrm{X}$ PBS containing 30\% polypropylene glycol (and 1\% BSA if using cells) at room temperature for $2 \mathrm{~h}$.

5. Prepare samples for freezing:

i. If the subjects are cells, centrifuge to concentrate, aspirate off the medium, and transfer the cells to a small piece of aluminum foil.

ii. If the subject is a small piece of tissue, drain it and transfer it to foil.

6. Freeze the samples:

i. Freeze cells or small pieces of tissue in liquid propane cooled in liquid nitrogen.

ii. Alternatively, if the subject is to be cryoimmobilized without chemical fixation, freeze it by impact against a gold-coated copper block.

7. Under liquid nitrogen, transfer cells or small pieces of tissue to the automated freeze substitution system and incubate for $24 \mathrm{~h}$ at $-90^{\circ} \mathrm{C}$ in vials half-filled with uranyl acetate $(0.05 \%)$ in $100 \%$ methanol.

Chilled metal forceps are often used to move samples, and tissues frequently develop a "charge," causing them to stick to the forceps. A cooled wooden cocktail stick can be used to dislodge them, or ceramic forceps can be used if necessary.

8. Warm samples to $-70^{\circ} \mathrm{C}$ and maintain for $24 \mathrm{~h}$.

9. Warm samples to $-50^{\circ} \mathrm{C}$ and rinse in four changes of pure methanol over a period of $2 \mathrm{~h}$.

10. Mix and deoxygenate $100 \% \mathrm{HM} 20$ resin by bubbling dry nitrogen gas through it for $5 \mathrm{~min}$.

11. Incubate samples in a 50:50 mixture of 100\% methanol and 100\% HM20 resin at room temperature overnight.

12. Incubate samples in $100 \% \mathrm{HM} 20$ resin at room temperature for $4 \mathrm{~d}$, changing the resin daily.

13. Polymerize the resin by UV irradiation for $24 \mathrm{~h}$ at $-50^{\circ} \mathrm{C}, 24 \mathrm{~h}$ at $-40^{\circ} \mathrm{C}$, and $48 \mathrm{~h}$ at $15^{\circ} \mathrm{C}$.

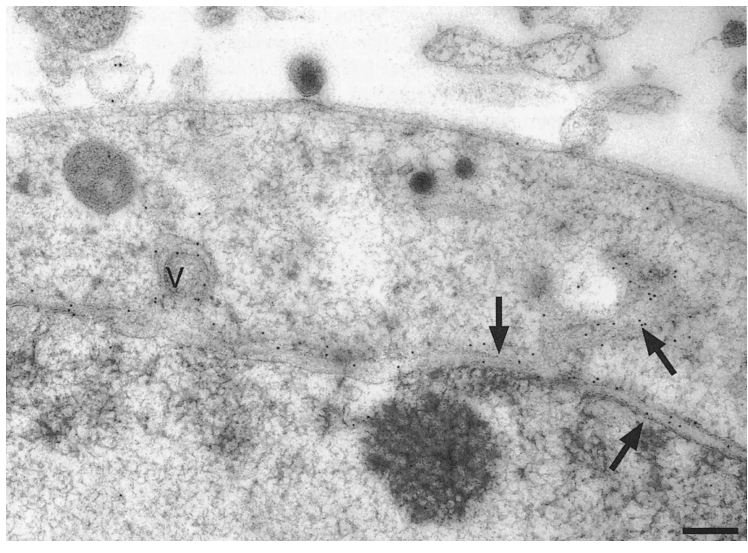

FIGURE 1. Thin section of a Vero cell infected with human papilloma virus. Cells were quench frozen in melting propane cooled in liquid nitrogen, dehydrated by freeze substitution against pure methanol containing $0.1 \%$ uranyl acetate, and low-temperature embedded in Lowicryl HM20. Cells were immunolabeled for glycoprotein D. Gold particles indicate the nuclear membrane and the rough endoplasmic reticulum (arrows) and the membrane acquired by a virus particle $(\mathrm{V})$ that has just budded through the nuclear envelope. Bar, 200 $\mathrm{nm}$. (Reprinted with permission from Scion Publishing Ltd. (C) 2006.) 


\section{Sectioning and Staining}

All nickel grid incubations/rinses should be performed on dental wax.

14. Cut thin sections $(50-70 \mathrm{~nm})$ of embedded samples and mount onto nickel grids.

15. Incubate sections on drops of PBSG at room temperature for $10 \mathrm{~min}$.

16. Incubate sections on drops of optimally diluted primary antibodies in PBSG at room temperature overnight.

17. Rinse sections on ten $100-\mu \mathrm{L}$ drops of $1 \mathrm{X}$ PBS for 2 min on each drop.

18. Incubate sections on drops of optimally diluted species-specific secondary antibodies in PBSG (conjugated to 10- or 15-nm gold particles) at room temperature for $2 \mathrm{~h}$.

19. Rinse sections in $\mathrm{H}_{2} \mathrm{O}$ for $30-40 \mathrm{sec}$.

20. Counterstain sections by floating grids section-side down on drops of uranyl acetate (saturated) in $50 \%$ methanol for $0.5-10 \mathrm{~min}$ at room temperature. Follow with a rinse in $50 \%$ methanol and a rinse in $\mathrm{H}_{2} \mathrm{O}$ (Gibbons and Grimstone 1960).

21. Counterstain sections by floating grids section side down on drops of lead citrate (Reynolds 1963) for 0.5-10 min at room temperature in a Petri dish containing a few grains of moistened potassium hydroxide (to prevent lead carbonate precipitation).

22. Rinse grids extensively in $\mathrm{H}_{2} \mathrm{O}$ and view at $80 \mathrm{kV}$ in a transmission electron microscope.

\section{DISCUSSION}

Prior to low-temperature embedding, lightly fixed pieces of tissue should be cryoprotected by immersion in 30\% glycerol or polypropylene glycol (Zajicek et al. 1995). The cryoprotectant provides many nucleation sites within the tissue, so that, even when slower freezing methods are used, the small ice crystals formed are unresolvable by TEM at the magnifications used for most immunogold staining studies. The method described here has been used successfully to localize adhesion molecules (Zajicek et al. 1995), which are notoriously labile during fixation and embedding.

\section{REFERENCES}

Gibbons, I.R. and Grimstone, A.V. 1960. On flagellar structure in certain flagellates. J. Biophys. Biochem. Cytol. 7: 697-716.

Griffiths, G., Burke, B., and Lucocq, J. 1993. Fine structure immunocytochemistry. Springer-Verlag, Heidelberg, Germany.

Monaghan, P. and Robertson, D. 1990. Freeze-substitution without aldehyde or osmium fixatives: Ultrastructure and implications for immunocytochemistry. J. Microsc. 158: 355-363.

Reynolds, E.S. 1963. The use of lead citrate at high $\mathrm{pH}$ as an electronopaque stain in electron microscopy. J. Cell Biol. 17: 208-212.

Skepper, J.N. 2000. Immunocytochemical strategies for electron microscopy: Choice or compromise. J. Microsc. 199: 1-36.

Skepper, J.N. and Powell, J.M. 2008a. Ultrastructural immunochemistry. CSH Protocols (this issue) doi: 10.1101/pdb.top47.

Skepper, J.N. and Powell, J.M. 2008b. Immunogold staining of epoxy resin sections for transmission electron microscopy (TEM). CSH Protocols (this issue) doi: 10.1101/pdb.prot5015.
Skepper, J.N. and Powell, J.M. 2008c. Immunogold staining of London Resin (LR) White sections for transmission electron microscopy (TEM). CSH Protocols (this issue) doi: 10.1101/ pdb.prot5016.

Skepper, J.N. and Powell, J.M. 2008d. Immunogold staining of ultrathin thawed cryosections for transmission electron microscopy (TEM). CSH Protocols (this issue) doi: 10.1101/pdb.prot5018.

Skepper, J.N., Whiteley, A., Browne, H., and Minson, A. 2001. Herpes simplex virus nucleocapsids mature to progeny virions by an envelopment $\rightarrow$ deenvelopment $\rightarrow$ reenvelopment pathway. J. Virol. 75: 5697-5702.

Zajicek, J., Wing, M., Skepper, J., and Compston, A. 1995. Human oligodendrocytes are not sensitive to complement. A study of CD59 expression in the human central nervous system. Lab. Invest. 73: 128-138. 


\title{
Immunogold Staining Following Freeze Substitution and Low Temperature Embedding after Chemical Fixation or after Cryoimmobilization for Transmission Electron Microscopy (TEM)
}

\author{
Jeremy N. Skepper and Janet M. Powell
}

Cold Spring Harb Protoc; doi: 10.1101/pdb.prot5017

\begin{tabular}{|c|c|}
\hline $\begin{array}{r}\text { Email Alerting } \\
\text { Service }\end{array}$ & Receive free email alerts when new articles cite this article - click here. \\
\hline $\begin{array}{c}\text { Subject } \\
\text { Categories }\end{array}$ & $\begin{array}{l}\text { Browse articles on similar topics from Cold Spring Harbor Protocols. } \\
\text { Antibodies, general (289 articles) } \\
\text { Cell Biology, general (1382 articles) } \\
\text { Cell Imaging (525 articles) } \\
\text { Electron Microscopy ( } 43 \text { articles) } \\
\text { Imaging/Microscopy, general (579 articles) } \\
\text { Immunohistochemistry ( } 92 \text { articles) } \\
\text { Immunoimaging (41 articles) } \\
\text { Immunology, general (128 articles) } \\
\text { Immunostaining (139 articles) } \\
\text { Immunostaining Cells (51 articles) } \\
\text { Labeling for Imaging ( } 339 \text { articles) } \\
\text { Phenotypic Analysis (42 articles) } \\
\text { Visualization (524 articles) } \\
\text { Visualization of Gene Expression (127 articles) } \\
\text { Visualization of Organelles (88 articles) }\end{array}$ \\
\hline
\end{tabular}

